\title{
Kronik Böbrek Yetmezliği Gelişen Diyabetli Bireylerde Beslenme Tedavisi
}

\author{
Nutrition Therapy in Diabetic Individuals with Chronic Renal Failure
}

\author{
Perim F. Türker ${ }^{1}$
}

Geliş tarihi/Received: 12.01.2019 • Kabul tarihi/Accepted: 08.11.2019

\section{ÖZET}

Kronik böbrek yetmezliği (KBY), glomerül filtrasyon hızının (GFH) böbrek fonksiyonlarında tespit edilebilir düzeyde değişikliklere neden olacak kadar, kalıcı bir şekilde azaldığı durum olarak tanımlanabilir. Bu durum genellikle GFH 60 mL/ dk/1.73 m²nın altına indiğinde ortaya çıkar. Son dönem böbrek yetmezliği (SDBY), endojen renal fonksiyonunun irreversibl kaybı ile karakterize ve hayatı tehdit eden üremiden korunmak için hastaya devamlı olarak diyaliz veya transplantasyon gibi renal replasman tedavilerinin uygulandığı klinik tabloyu oluşturur. Diyabetik nefropati, son dönem böbrek yetmezliği nedenleri arasında birinci sırada yer almaktadır. Diyabetik nefropati, idrarla anormal albumin/protein atılımı, giderek azalan renal fonksiyonlara eşlik eden hipertansiyon (HT), GFH devamlı düşme, kardiyovasküler risk faktörlerinin artmasıyla karakterize son dönem böbrek yetmezliği ile sonuçlanan klinik durumdur. Diyabetik nefropatide kan glukozu, kan basıncı, kan lipidlerinin kontrolü ve tıbbi beslenme tedavisi özellikle diyet proteinin kontrolü hastaların yaşam kalitesini arttırmaktadır.

Anahtar kelimeler: Kronik böbrek yetmezliği, diyabetes mellitus, nefropati, beslenme tedavisi

\begin{abstract}
Chronic kidney disease (CKF) is a state of permanent decrease in glomerular filtration rate (GFR) that will cause established changes in kidney functions. This status usually occurs when GFR decreases below $60 \mathrm{~mL} / \mathrm{min} / 1.73 \mathrm{~m}^{2}$. End Stage Renal Disease (ESRD) is characterized with irreversible loss of renal functions and this constitutes a clinical state that requires renal replacement treatments such as dialysis and transplantation in order to be protected from harmful and life threatening effects of uremia. Diabetic nephropathy, is the first leading cause of end stage renal diseases. Diabetic nephropathy is a clinical condition that results in end-stage renal failure characterized by abnormal albumin / protein excretion in the urine, progressive decline in glomerular filtration rate, hypertension (HT) accompanied by decreasing renal function, and increased cardiovascular risk factors. Control of blood glucose, blood pressure, blood lipids and medical nutrition therapy, especially the control of dietary protein in diabetic nephropathy, increases the quality of life of patients.
\end{abstract}

Keywords: Chronic kidney disease, diabetes mellitus, nephropathy, nutritional therapy

1. İletişim/Correspondence: Başkent Üniversitesi, Sağllk Bilimleri Fakültesi, Beslenme ve Diyetetik Bölümü, Ankara, Türkiye

E-posta: pfturker@baskent.edu.tr • ๑ https://orcid.org/0000-0002-4254-3711 


\section{GíRiş}

Böbrekler, vücudun sıvı ve elektrolit dengesinin sağlanmasından, metabolik atıkların (üre, ürik asit ve kreatinin) kandan uzaklaştırılmasından, kan basıncinin kontrolünden, hormon üretiminden sorumludurlar (1). Kronik böbrek hastalığı $(\mathrm{KBH})$, çeşitli hastalıklara bağlı olarak gelişen kronik, ilerleyici (progresif) ve geri dönüşümsüz (irreversible) nefron kaybı sonucu gelişen, glomerül filtrasyon hızının (GFH) böbrek fonksiyonlarında tespit edilebilir düzeyde değişikliklere neden olacak kadar, kalıcı bir şekilde azaldığı $(\mathrm{GFH}<60 \mathrm{~mL} / \mathrm{dk} / 1.73$ $\mathrm{m}^{2}$ ) bir hastalıktır. Ayrıca, KBH'yi, GFH'ın azalması sonucu böbreğin sıvı-solüt dengesini ayarlama ve metabolik-endokrin fonksiyonlarında kronik ve ilerleyici bozulma hali olarak ve sıklıkla son dönem böbrek yetmezliğine (SDBY) götüren pek çok etyolojik sebebi olan patofizyolojik bir süreç olarak da tanımlanmaktadır. GFH $15 \mathrm{~mL} / \mathrm{dk} / 1.73 \mathrm{~m}^{2}$ ye inince SDBY'den bahsedilir. SDBY'de, endojen renal fonksiyonunun irreversibl kaybı ile karakterize ve hayatı tehdit eden üremiden korunmak için hastaya devamlı olarak diyaliz veya transplantasyon gibi renal replasman tedavileri uygulanir (2). Amerika Birleşik Devletleri'nde 2002 yllında Ulusal Böbrek Vakfı Böbrek Hastalığı Sonuçları Kalite Girişimi tarafindan (National Kidney Foundation-Kidney
Disease Outcomes Quality Initiative [NKF/KDOQI]) kronik böbrek hastalığı şiddeti ile ilgili bir kılavuz hazırlanmıştır. Bu kılavuzda kronik böbrek hastalığı şiddeti Tablo 1'de gösterildiği gibi evrelendirilmiştir $(3,4)$.

Türk Nefroloji Derneği (TND) tarafından gerçekleştirilen CREDIT çalışması, Türkiye'de erişkinlerin \%15.7'sinde kronik böbrek yetmezliği (KBY) bulunduğunu göstermiştir (5). TND Böbrek Kayıt Sistemi verilerine göre ülkemizde SDBY’nin prevalansı giderek artmaktadır (6). Türkiye’de 2017 yılı SDBY insidansı milyon nüfus başına 146/milyon, prevalansı ise 957/milyon olarak saptanmıştır (7). Bu derleme makalede, kronik böbrek yetmezliği gelişen diyabetli bireylerde güncel tıbbi beslenme tedavileri irdelenmiştir.

\section{Kronik Böbrek Hastalığı Risk Faktörleri}

KBH'a yol açan nedenlerin dağılımı ülkeye, ırka, yaşa ve cinsiyete göre farklılıklar göstermek ile birlikte giderek artan oranda görülen diyabet, ileri yaş, hipertansiyon (HT) ülkemizde de önde giden risk faktörleri arasında gelmektedir. $\mathrm{KBH}$ için kabul edilen risk faktörleri Tablo 2'de görülmektedir. Eşlik eden hastalığı olan bireylerde KBY gelişme riski daha yüksektir $(5,8)$.

Tablo 1. Kronik böbrek hastalığı evrelendirmesi (4)

\begin{tabular}{lll}
\hline Evre & Tanımlama & GFH (mL/dk/1.73 $\left.\mathbf{~ m}^{2}\right)$ \\
\hline Evre 1 & GFH normal veya artmış, GFH ile böbrek hasarı & $\geq 90$ + Hasar belirteçleri \\
Evre 2 & Hafif GFH azalması & $60-89+$ Hasar belirteçleri \\
Evre 3a & Hafif-Orta GFH azalması (mikroalbüminüri gelişimi) & $45-59$ \\
Evre 3b & Orta-şiddetli GFH azalması & $30-44$ \\
Evre 4 & Şiddetli GFH azalması (aşikar nefropati dönemi) & $15-29$ \\
Evre 5 & Son dönem böbrek yetmezliği & $<15$ \\
\hline
\end{tabular}

GFH: Glomerul filtrasyon hizı

Tablo 2. Kronik böbrek hastalığı risk faktörleri $(5,8)$

\begin{tabular}{lll}
\hline İleri yaş & Diabetes Mellitus & Kontrolsüz hipertansiyon \\
Ailede KBY öyküsü & Kötü glisemik kontrol & Obezite \\
Dislipidemi & Sistemik infeksiyonlar & Otoimmun hastalılar \\
Üriner infeksiyonlar & İlaç toksisitesi & Düşük sosyoekonomik ve eğitim düzeyi \\
\hline
\end{tabular}


KBY sıklığındaki artışın en önemli iki nedeni; toplumun yaş ortalamasının giderek artması ve ülkemizde diyabetin epidemi haline gelmesidir (8). KBY etiyolojileri ülkeden ülkeye farklılık göstermekle beraber dünyanın her yerinde diyabete bağlı KBY ve/ veya SDBY oluşumu giderek artmaktadır. Geçmişte en önemli KBY nedeni glomerulonefrit olmasına karşın, günümüzde Amerikan Böbrek Veri Sistemi (The United States Renal Data System [USRDS]) verilerine bakıldığında SDBY'ye neden olan etmenlerin arasında ilk sırada diyabetin, ikinci sırada HT’nin yer aldığı, kronik glomerülonefritin ise etiyolojide üçüncü sırayı izlediği bildirilmektedir (9). Türk Nefroloji Derneği 2017 yll verilerine göre ise Türkiye'de görülen en önemli etiyolojik faktörler tip 2 diyabet (\%38.03), HT (\%27.46), kronik glomerulonefrittir (\%6.01) (7). Hemodiyalize giren SDBY olan diyabetik hastalarda diyabetik olmayan hastalara göre kalp yetmezliği, iskemik kalp hastalığı ve sol ventrikül hipertrofi görülme oranı daha yüksek bulunmuştur (10).

\section{Diyabetik Nefropatinin Tanımı, Epidemiyolojisi}

Diyabetik Nefropati (DN), idrarla anormal albumin/ protein atılımı, giderek azalan renal fonksiyonlara eşlik eden HT, glomerüler filtrasyon hızında devamlı düşme, kardiyovasküler risk faktörlerinin artmasıyla karakterize son dönem böbrek yetmezliği ile sonuçlanan klinik durumdur. DN, son dönem böbrek yetmezliği nedenleri arasında birinci sırada yer almakta (11) ve tüm diyabetlilerin \%20-40'ında görülmektedir (5). Böbrek hasarının göstergesi olan mikroalbüminüri oranı \%10.2, makroalbüminüri oranı ise \%2'dir (5). DN sıklığı, diyabet süresi uzadıkça artış gösterir. Yirmi beş yıldan daha fazla süredir diyabeti olanların yaklaşık \%25-40'ında DN gelişmektedir (12).

\section{Diyabetik Nefropatinin Patogenezi ve Tanısı}

Hücre içi sinyal molekülleri, sitokin, büyüme faktörleri, genetik, metabolik etmenler (hiperglisemi, AGE birikimi, oksidatif stres), renin anjiyotensin sistemi, hemodinamik, hipertansiyon ve hiperglisemi DN patogenezinde rolü olan faktörlerdir. Diyabetik hastalarda renal tutulumun en erken yansiması mikroalbuminüridir. Tip 1 ve tip 2 diyabette böbrek lezyonlarının patofizyolojisi benzer olmakla birlikte tip 1 diyabetli bireylerde DN gelişmesinde hipergliseminin payı büyüktür (12). Renal tutulumun en erken klinik yansıması mikroalbuminüridir (13). Mikroalbuminüri tanısı için sabah ilkidrarda albumin/ kreatinin oranı (mg/g) bakılmalıdır. Türk Diyabet Vakfı 2019 Diyabet Tanı ve Tedavi Rehberi'nde yer alan DN tanı kriterlerine göre üriner albumin atımı 30 mg/g kreatinin ve üzeri ise (30-300 mg/g) mikroalbuminüri tanısı konulur. Mikroalbüminürinin etkilendiği durumlar ise; egzersiz, ateş, gebelik, diyetle protein ve sıvı alımıdır (14). Ayrıca, erişkinlerde erken dönem nefropatiyi araştırmak için mikroalbuminüri ile birlikte tahmini glomerüler filtrasyon hızının (eGFH) hesaplanması da gerekir $(14,15)$.

\section{Diyabetik Nefropatinin Önlenmesi}

DN'nin önlenmesi üç ana başlık altında toplanmaktadır. Bunlar;

1. Primer Korunma: Mikroalbüminüriden korunma,

2. Sekonder Korunma: Mikroalbuminüriden makroalbuminüriye geçişten korunma,

3. Tersiyer Korunma: Böbrek yetmezliğine ilerlemesinin yavaşlatılmasıdır.

Kan glukozu, kan basincı, kan lipidlerinin kontrolü ve tıbbi beslenme tedavisi özellikle diyet proteinin kontrolü DN'li hastaların yaşam kalitesini arttırmaktadır (16).

\section{Kan glukoz kontrolü}

Hastalarda açlık kan glukozu 80-130 mg/dL, postprandiyal kan glukozu $<180 \mathrm{mg} / \mathrm{dL}$ ve $\mathrm{HbA} 1 \mathrm{c}$ değerinin $<\% 7$ olarak hedeflendiğinde hiperfiltrasyon ve renal hipertrofinin önlendiği, mikroalbuminürinin gelişiminin geciktiği, glomerüler hipertansiyonun düzeldiği belirtilmektedir (14,16). Bireyin kan glukoz düzeyine, fiziksel aktivite durumuna ve besin tüketimine göre; doğru insülin doz ayarlaması, doğru tıbbi beslenme tedavisi uygulaması ve vücut 
ağırlık kontrolü sonucunda da hiperfiltrasyonda ve proteinüride azalma görülmektedir. Ayrıca sıkı glisemi kontrolünün mikroalbuminüri gelişimini önlediği veya geciktirdiği, glomerüler hipertansiyonu düzelttiği, aşikar nefropatiyi olumlu etkilediği belirtilmektedir (17). Hastaların diyetle günde 20-25 g posa alımına teşvik edilmesi ve düşük glisemik indeksli besinlerin önerilmesi diyabetik nefropatiyi geciktirdiği, kan glukozunu iyileştirdiği belirtilmektedir.

\section{Kan basıncı kontrolü}

Hipertansiyon, diyabetik bireylerde diyabetik olmayan bireylere göre en az 2 kat daha fazladır ve mikrovasküler komplikasyonlar için majör bir risk faktörüdür. HT’nin kontrolünde amaç, proteinüri ve glomerüler yapısal lezyonların oluşumunu önlemektir. Tedavide hedeflenen kan basincı $\leq 140 / 90$ mmHg olmalıdır. Böbrek yetmezliği varsa hedef kan basıncl $<130 / 80$ mmHg olmalıdır. Hedef kan basıncına ulaşmak için günlük diyetle tuz alımı kısıtlanmalı (<46 g/gün), birey kilolu veya obez ise bireye özgü vücut ağırlık kontrol programı uygulanmalı, ayrıca sebze, meyveden yani posadan zengin, doymuş yağlardan ve kırmızı etten fakir diyet (Dietary Approaches to Stop Hypertension [DASH] veya Akdeniz diyeti) uygulanmalı ve fiziksel aktivite arttırılmalıdır (14).

\section{Kan lipidlerinin kontrolü}

Diyabetik hastalarda inflamasyon ve oksidatif stres ile glikozillenmiş son ürünlerdeki (Advanced Glycation End Products [AGE]) artış sonucu glomerüler hasar gelişip dislipidemiye neden olmaktadır. Yani, hastalarda GFR $<50 \mathrm{~mL} / \mathrm{dk} / 1.73 \mathrm{~m}^{2}$ ise dislipidemi gelişmektedir. Amerikan Ulusal Kolesterol Eğitim
Programı-Yetişkin Tedavi Paneli III (National Cholesterol Education Progran, Adult Treatment PanelIII [NCEP-ATP III]) hedeflerine bakıldığında; diyabetik dislipidemi tedavisinde primer hedef düşük dansiteli lipoprotein kolesterolün (low density lipoprotein/ LDL-kol) <100 mg/dL ve kardiyovasküler hastalıkları olan bireylerde ise $<70 \mathrm{mg} / \mathrm{dL}$ 'dir. Sekonder hedef ise; aterojonik kolesterolün yeni bir formu olan Non HDLkolesterol için <130 mg/dL'dir (18). Amerikan Diyabet Birliğine (American Diabetes Association [ADA]) göre; primer hedef LDL kolesterol'ün $<100 \mathrm{mg} / \mathrm{dL}$ olması, sekonder hedef ise HDL kolesterol'ün erkeklerde $>40$ $\mathrm{mg} / \mathrm{dL}$, kadınlarda $>50 \mathrm{mg} / \mathrm{dL}$ olmasıdır. Yüksek kan trigliserit seviyeli ( $\geq 150 \mathrm{mg} / \mathrm{dL}$ ), yüksek LDL kolesterol düzeyli ( $>100 \mathrm{mg} / \mathrm{dL}$ ) ve/veya düşük HDL kolesterol düzeyli ( $<40 \mathrm{mg} / \mathrm{dL}$ erkek, $<50 \mathrm{mg} / \mathrm{dL}$ kadın) hastalar için yoğun yaşam tarzı değişikliği tedavisi ve glisemik kontrolün sağlanması önerilmelidir (15). NKF/KDOQI kılavuzuna göre yaşam tarzı değişikliği; beden kütle indeksi (BKI)'nin 25-28 kg/m² arasında tutulması, diyet modifikasyonu, alkol alımının azaltılması, sigaranın bırakılması, haftada iki-üç kez 20-30 dakika fiziksel aktivite yapılması, obez veya fazla kilolu bireylerde vücut ağırlık kaybının sağlanmasıdır (19). Diyabetlilerde dislipideminin önlenmesi için ADA’nın kanıta dayalı tıbbi beslenme tedavisi önerileri Tablo 3’te gösterilmiştir (15). Hastalarda statin ve omega 3 kullanımı ile düzenli fiziksel aktivite ve iyi bir metabolik kontrolle böbrek fonksiyonları düzelme, mikroalbüminüride azalma ve kan basıncında düşme görülmektedir.

SDBY'de böbrek fonksiyonlarında azalma sonucu plazma lipit düzeyleri, lipoproteinler ve apolipoproteinlerin miktar ve kompozisyonunda önemli değişiklikler oluşur ve anormal lipit metabolizması gelişir. Bu hastalarda serum çok

Tablo 3. Diyabetlilerde dislipideminin önlenmesinde TBT önerileri (15)

\begin{tabular}{lcc}
\hline Bileşen & Öneri & Kanit düzeyi \\
\hline Doymuş yağ asitleri & $<\% 7$ & A \\
Kolesterol & $<200 \mathrm{mg} /$ gün & $\mathrm{E}$ \\
Balık tüketimi, 2 kez/haftada & $150-200 \mathrm{~g} /$ gün & B \\
Toplam etki & LDL kolesterol & $\% 20-30 \downarrow$ \\
\hline
\end{tabular}


düşük dansiteli lipoprotein (VLDL) ve düşük dansiteli lipoprotein (LDL) düzeyi yükselir ve serum yüksek dansiteli lipoprotein (HDL) düzeyi düşer. Total kolesterol düzeyi yükselse de yükselmese de serum trigliserit düzeyleri artar ve insülin rezistansı hipertrigliseridemiye katkıda bulunur ayrıca diyaliz hastalarında Tip 4 hiperlipidemi insidansı gelişimi yüksektir (20). Diyabeti ve SDBY olan hastalarda düşük serum kolesterol düzeyi mortalite ile ilişkili olup malnutrisyona ve inflamasyona neden olmaktadır. Böyle bir durumda hastalara uygulanan diyaliz tedavisine göre diyetle protein alımı arttırılmalıdır. Diyabete bağlı böbrek yetmezliğinde şiddetli inflamasyona bağlı hipoalbüminemi gelişir ve hastaların HDL kolesterol düzeyleri düşer. Diyabete bağlı böbrek hastalığında; lipit kılavuzları ve tıbbi beslenme tedavisi üremik olmayan bireyler ile aynıdır. Günlük diyet enerjisinin \%25-30'unun toplam yağ, <\%7'sinin doymuş yağ asitleri, <\%10'unun çoklu doymamış yağ asitleri, <\%20'sinin tekli doymamış yağ asitlerinden gelmesi, dislipidemiyi azaltmak için günlük 20-30 g posa (5-10 g çözünür posa) alımının ayarlanması, sukroz alıminin azaltılması ve diyetle günlük kolesterol alımının <200 mg olması gereklidir (21).

\section{Diyabetik Nefropatide Tıbbi Beslenme Tedavisi}

\section{Diyet proteini ve enerji gereksinimi}

Nefropati gelişmiş diyabetli bireylere önerilen düşük proteinli diyetlerin ( $<0.6 \mathrm{~g} / \mathrm{kg} / \mathrm{gün})$, üremik semptomları azalttığı, renal progresyonu önlediği ancak malnutrisyonu da geliştirdiği çalışmalarda belirtilmektedir. Günde $<0.6 \mathrm{~g} / \mathrm{kg}$ proteinli diyetle beslenen hastalarda malnutrisyonla birlikte negatif azot dengesi ve kas kütlesi azalması da görülmektedir. Bunun için; bu grup hastalarda proteinden kısıtlı diyet verilirken vücut ağırlığının değişmemesi, serum albümininin $>4 \mathrm{~g} / \mathrm{dL}$ ve serum transferin düzeyinin $>200 \mathrm{mg} / \mathrm{dL}$ 'nin üzerinde olması amaçlanmalıdır. Diyabete bağlı böbrek hastalığı gelişmiş bireylerde mikroalbuminüri saptanmış ise diyet protein alımı $<0.8-1 \mathrm{~g} / \mathrm{kg} / \mathrm{gün}$, makroalbuminüri geliştiyse $0.8 \mathrm{~g} / \mathrm{kg} /$ gün önerilmektedir. Ayrıca protein kaynağının \%50 ile \%75'inin yüksek biyolojik değere sahip olması gerekmektedir (14).

NKF kılavuzları; KBY olan hastalara mutlaka tıbbi beslenme tedavisinin verilmesi gerektiğini, diyet modifikasyonlarının KBY hastalarının progresyonunu önlediğini belirtmektedir. KBY'nin 1. ve 2. evrelerinde olan DN'li hastalarda protein gereksinimi $0.8 \mathrm{~g} / \mathrm{kg} / \mathrm{gün}$, evre 3 ve 4'de olan KBY hastasinda ise 0.6-0.8 g/ $\mathrm{kg} / \mathrm{gün}$ olarak ayarlanmalıdır (B Kanıt Düzeyi) (22). Diyabetik hastalarda diyet enerjisinin proteinden gelen oranının $>\% 20$ olduğu diyetlerin kullanımının uzun süreli etkileri bilinmediğinden enerjinin proteinden gelen oranının <\%20 olması gerektiği düşünülmektedir (13). Diyet enerjisinin proteinden gelen oranının $>\% 20$ olması durumunda böbrek işlev kaybı görüldüğü, diyabet ve HT'si olan bireylerde ise mikroalbuminüri geliştiği belirtilmektedir (21). DN'nin beşinci evresi olan SDBY'de hemodiyaliz (HD) uygulanan hastalarda seans boyunca 8-12 g aminoasit sürekli ayaktan periton diyaliz (SAPD) uygulanan hastalarda 5-15 g protein/gün ve peritonit gelişen hastalarda ise $30 \mathrm{~g}$ protein/gün kaybı olduğundan malnütrisyon gelişebilmektedir. Bu protein kayıplarından dolayı Avrupa Klinik Nütrisyon ve Metabolizma Derneği

Tablo 4. KBY ve renal replasman tedavisi (HD-SAPD) alan hastalarda günlük enerji ve besin ögesi gereksinimleri (23)

\begin{tabular}{llll}
\hline Enerji ve besin ögeleri (gün) & KBY & HD & SAPD \\
\hline Enerji (kkal/kg) & $>35$ & $\geq 35(>\% 50 \mathrm{HBV})$ & $\geq 35(>\% 50 \mathrm{HBV})$ \\
Protein $(\mathrm{g} / \mathrm{kg})$ & $0.6-1.0$ & $1.0-1.2$ & $1.2-1.5$ \\
Fosfor $(\mathrm{mg})$ & $600-1000$ & $800-1000$ & $800-1000$ \\
Potasyum $(\mathrm{mg})$ & $1500-2000$ & $2000-2500$ & $2000-2500$ \\
Sodyum (g) & $1.8-2.5$ & $1.8-2.5$ & $1.8-2.5$ \\
Sivı (mL) & Kisitlama yok & $1000+$ idrar volümü & $1000+$ idrar volümü \\
\hline
\end{tabular}


(European Society for Clinical Nutrition and Metabolism [ESPEN]) nutrisyon rehberine göre stabil KBY ve renal replasman tedavisinde olan hastalarda enerji ve besin ögeleri gereksinimleri Tablo 4'de özetlenmiştir (23).

Diyalize girmeyen KBY'li hastaların enerji gereksinimi diğer sağlıklı bireylerle aynıdır. NKF/DOQI önerilerine göre; 60 yaş altında ve $\mathrm{GFH}<25 \mathrm{~mL} / \mathrm{dk}$ olan hastalarda enerji gereksinimi $35 \mathrm{kkal} / \mathrm{kg}$ (ideal vücut ağırlı̆̆ı)/ gün; 60 yaş üzerinde olanlarda ise $30-35 \mathrm{kkal} / \mathrm{kg}$ (ideal vücut ağırlığı)/gün önerilmektedir. Hasta obez ise 25-

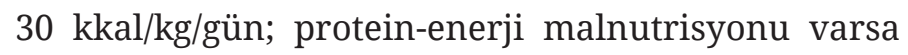
$>35 \mathrm{kkal} / \mathrm{kg} /$ gün verilmektedir. Bu grup hastalarda protein gereksinimi prediyaliz döneminde 0.6-0.75 g/ kg/gün; HD’de 1.2 g/kg/gün; periton diyalizinde 1.2-1.4 g/kg/gün (\%50’si yüksek biyolojik değerlikli) olmalıdır (22). ADA, diyabetik nefropatisi olan hastalar için 0.8 g/kg/gün protein alımı önermektedir (13).

\section{Karbonhidratlar ve Yağlar}

KBY'de glukoz metabolizması ve insülin direnci bozulmaktadır. Glukoz metabolizmasını düzeltmek, nonprotein enerjiyi yeterince sağlamak, enerji yetersizliğini önlemek için diyet günlük enerjinin \%55-60’ı karbonhidratlardan (KH) gelecek şekilde düzenlenmelidir (17). Aşırı karbonhidrat tüketimi, hipertrigliseridemiye neden olabileceğinden hipertrigliseridemi insidansinin azaltılması ve gerekli durumlarda glukoz toleransının iyileştirilmesi için hastaya saf KH'lerde ziyade kompleks KH'ler önerilmelidir. Diyabetik nefropatinin önlenmesinde ayrıca düşük glisemik indeks ve glisemik yüklü diyetler kan glukoz düzeylerinde anlamlı bir düzelme sağlamakta ve tokluk kan şekerini düşürebilmektedir. Hastalar diyetle günde 20-25 g posa alımına teşvik edilmelidir (17).

Amerikan Kalp Birliğinin (American Heart Association [AHA]) önerileri doğrultusunda primer hedef yükselmiş serum LDL kolesterol düzeyleri ise günlük enerjinin <\%30'unun yağlardan <\%7'sinin doymuş yağlardan karşılanması diyet ile kolesterol alımının $<200$ mg/gün olması önerilmektedir. Serum trigliserit düzeyi 1000 mg/dL'den yüksek bireylerde tüm yağ tiplerinin azaltılması gerekmektedir. Diyabetik nefropatide omega 3 yağ asidi içeriği yüksek olan besinler tercih edilmelidir (13).

\section{Potasyum}

Diyet potasyum kısıtlanmasının derecesi renal ve renal olmayan kayıpların miktarına bağlıdır. KBY'de serum potasyum düzeyi yükseldiğinde hastada kardiak arrest, aritmi ve kas zayıflı̆̆ görülebilmektedir. Eğer hastalarda idrar miktarı azaldıysa veya anürik ise hiperkaleminin önüne geçebilmek için diyetteki potasyum miktarının genellikle kısıtlanmasına ihtiyaç vardır. Bu yüzden beşinci evrede HD hastalarında günlük potasyum alımı 1600-2000 mg iken SAPD hastalarında ise 2000-3000 mg/gün'dür. Belirgin derecede rezidüel idrar miktarı olan ve evresi 3. ve 4 . olan KBY'li hastalarda ise 2000-4000 mg/gün potasyum alımı önerilmektedir. DN'nin 1. ve 2. evresinde ise diyetle potasyum alımı >4000 mg/gün olmalıdır (24).

\section{Kalsiyum/Fosfor}

DM'li hastalarda diyetle fosfor alımı 1. ve 2.evrede normal düzeydedir. Ancak KBY’nin, 3. ve üzeri evreleri fosforun renal atımında yetersizliğe neden olmaktadır. Bu nedenle özellikle 5. evre KBY olan hastalarda (HD ve SAPD) günlük fosfor alımı 0.81.2 g/gündür. Fosfor alımının kisıtlanmasıyla, HD hastalarının diyetleri kalsiyumdan da kısıtlı hale gelmektedir. Kalsiyum dengesini sağlamak için, HD hastalarma kalsiyum ve D vitamini verilmektedir. Fakat diyalize girmeyen KBY'li hastalarda olduğu gibi SAPD'li hastalarda kalsiyum ve $\mathrm{D}$ vitamini kullanımı ciddi hiperkalsemi ile sonuçlanıp renal osteodistrofiye neden olabileceğinden; bu tedavi dikkatli yapılmalıdır. Sonuçta; diyaliz hastalarında kalsiyum dengesini pozitif düzeyde tutabilmek için günde 1000-1500 mg kalsiyuma ihtiyaç vardır $(25,26)$.

\section{Sodyum/ Sivı}

KBY’nin yaşamsal önemi olan en önemli komplikasyonları sıvı-elektrolit bozukluklarıdır. $\mathrm{Bu}$ nedenle tedavide temel amaç sıvı ve elektrolit 
dengesinin sağlanması ve korunması olmalıdır. Hastaların sıvı ve elektrolit gereksinimi hastaların ödem, dehidrasyon, idrar miktarına ve hastaların böbrek yetmezliğinin derecesi göz önünde tutularak ayarlanmalıdır. Böbrek yetmezliğinin ilk evrelerinde sıvı ve sodyum kısıtlamasına gerek yoktur. Eğer KBY’li hastalarda ödem, hipertansiyon ve kalp yetmezliği yoksa evre 3 ve 4'de sıvı alımı tolere edilebiliyorsa kısıtlama yapılmamalıdır. Ancak bu hastalarda fazla sivı ve sodyum alımının hipervolemi, hipernatremi gibi sorunlara neden olabileceği de unutulmamalıdır. NKF/KDOQI verilerine göre evre 1 ve 4 arasında KBY ve HT'si olan hastalara günlük sodyum alımı 2.4 g'dan daha az olarak önerilmektedir. SDBY'de; HD uygulanan hastaların bir günde aldıkları sıvı miktarı; (24 x 0.5 x vücut ağırlığı + 1 gün önceki çıkardığı idrar miktarı) formülasyonuyla ayarlanmalıdır ve sodyum kısıtlaması idrar miktarına göre yapılmaktadır. İdrar miktarı günde 1 litreden fazla olan hastalarda yani oligürisi olanlarda 3-4 g/gün gibi hafif bir tuz kısıtlaması yeterli olmaktadır. Anürisi olan HD hastaları ise 1-1.5-2 g/gün civarında tuz ve en fazla 1 litre sıvı alabilmektedirler $(25,27)$.

\section{SONUÇ VE ÖNERILER}

Diyabetik nefropati, son dönem böbrek yetmezliği nedenleri arasında birinci sırada yer almaktadır. Diyabetik nefropati, idrarla anormal albumin/protein atılımı, giderek azalan renal fonksiyonlara eşlik eden hipertansiyon, GFH devamlı düşme, kardiyovasküler risk faktörlerinin artmasıyla karakterize son dönem böbrek yetmezliği ile sonuçlanan klinik durumdur. Diyabetik nefropatide kan glukozu, kan basıncl, kan lipidlerinin kontrolü ve tıbbi beslenme tedavisi özellikle diyet proteinin kontrolü hastaların yaşam kalitesini arttırmaktadır. Diyabetli bireylerde optimal metabolik kontrol ile nefropatinin önlenmesi ve nefropati gelişen diyabetlilerde bireye özgü tıbbi beslenme tedavisi ve uygun diyabet yönetimi ile son dönem böbrek yetmezliğinin gelişiminin önlenmesi büyük önem taşımaktadır.

Çıkar çatışması - Conflict of interest: Yazarlar çıkar çatışması olmadığını beyan ederler. - The authors declare that they have no conflict of interest.

\section{KAYNAKLAR}

4. Widmaier EP, Raff H., Strang KT. Böbrekler, su ve inorganik iyonların düzenlenmesi. Demirgören $S$, editör. Vander İnsan Fizyolojisi. 10. Baskı, Güven Kitabevi, İzmir 2010:490-532.

5. Tanrıverdi MH, Karadağ A, Hatipoğlu EŞ. Kronik böbrek yetmezliği. Konuralp Tıp Dergisi. 2010;2(2):27-32.

6. Levey AS, Eckardt KU. Definition and classification of chronic kidney disease. A position statement from Kidney Disease: Improving Global Outcomes. Kidney Int. 2005;67:2089-100.

7. National Kidney Foundation-K/DOQI Clinical practice guidelines for chronic kidney disease. Evalution classification and stratification. Am J Kidney Dis. 2007;49(2)(suppl 2):S13-S19.

8. Süleymanlar G, Utaş C, Arınsoy T. A population based survey of chronic renal disease in Turkey - The CREDIT study. Nephrol Dial Transplant. 2011;26:1862-71.

9. Plantinga LC, Boulware LE, Coresh J, Stevens LA, Miller ER, Saran R, et al. Patient awareness of chronic kidney disease. Trends and Predictors. Arch Intern Med. 2008;168:2268-75.

10. Süleymanlar G, Ateş K, Syahi N. T.C. Sağlık Bakanlığı ve Türk Nefroloji Derneği Ortak Raporu. Türkiye’de Nefroloji, Diyaliz ve Transplantasyon 2017 Raporu. Türk Nefroloji Derneği Yayınları, Ankara 2018;1:1-140.

11. Hallan SI, Coresh J, Astor BC. International comparison of the relationship of chronic kidney disease prevalence and ESRD risk. J Am Soc Nephrol. 2006;17:2275-84.

12. Yeniçerioğlu Y. Kronik böbrek hastalığı epidemiyolojisi. Türkiye Klinikleri J Nephrol. 2008;1(2):1-5.

13. Foley RN, Culleton BF, Parfrey JD, Harriett G. Cardiac disease in diabetic and end stage renal disease. Diabetologia. 1997;40:1307-12.

14. Mayfield JA, Reiber GE, Sanders LJ, Janisse D. Preventive foot care in people with diabetes. Diab Care. 2003;26(1):S78-S79.

15. Cooper ME. Pathogenesis, prevention and treatment of diabetic nephropaty. The Lancet. 1998;352:213-9.

16. ADA Position Statement. Nephropathy in diabetes. Diabetes Care. 2004;27(Suppl 1):79-83.

17. Balcı K. Türkiye Diyabet Vakfı, Diyabet Tanı ve Tedavi Rehberi-2019. Türk Diyabet Vakfı Yayınları, İstanbul 2019:1-192.

18. American Diabetes Association. Standards of medical care in diabetes. Diabetes Care. 2013;36(Suppl1):S11-S66.

19. TEMD Diyabetes Mellitus ve Komplikasyonlarının Tanı, Tedavi ve İzlem Kılavuzu-2011. Miki Matbaacılık, 5. Baskı, Ankara 2011:1-20.

20. Atalay Gören N, Kızıltan G. Diyabetik nefropatide tıbbi beslenme tedavisi. Bes Diy Derg. 2014;42(2):160-7. 
21. Expert Panel on Detection, Evaluation, and Treatment of High Blood Cholesterol in Adults. Executive summary of The Third Report of National Cholesterol Education (NCEP) Expert Panel on Detection, Evaluation, and Treatment of High Blood Cholesterol In Adults (Adult Treatment Panel III). JAMA. 2001;285:2486-97.

22. National Kidney Foundation. KDOQI clinical practice guidelines and clinical practice recommendations for diabetes and chronic kidney disease. Am J Kidney Dis. 2009;35(suppl2):1-140.

23. Scrhier R. Atlas of Diseases of the Kidney 1. 1th edition, Wiley- Blackwell, 1999.

24. Holben DH. Position of the American Dietetic Association: food insecurity in the United States. J Am Diet Assoc. 2010;110(9):1368-77.

25. National Kidney Foundation. KDOQI clinical practice guidelines and clinical practice recommendations for diabetes and chronic kidney disease. Am J Kidney Dis. 2007;49(suppl2):1-180.

26. Cano N, Fiaccadori E, Tesinsky P, Toigo G. ESPEN guidelines on enteral nutrition: Adult Renal Failure. Clin Nutr. 2006;25:295-310.

27. Fouque D, Vennegoor M, ter Wee P, Wanner C, Basci A, Canaud B, et al. EBPG guideline on nutrition. Nephrol Dial Transplant. 2007;22(Suppl 2):ii45-ii87.

28. Ash S, Campbell C, MacLaughlin H, Ash S, Campbell $\mathrm{K}$, MacLaughlin $\mathrm{H}$, et al. Evidence based practice guidelines for the nutritional management of chronic kidney disease. Nutr Diet. 2006;63(Suppl.2):S35-S45.

29. Kopple JD. K/DOQI clinical practice guidelines for nutrition for chronic dialysis patients. AJKD 2001;37(1):S66-S70.

30. Eknoyan G, Levin N, Kopple J, Fougue D, Cockram D, Burrowes J, et al. K/DOQI clinical practice guidelines for nutrition in chronic renal failure. AJKD 2000;35(6) (Suppl 2):S17-S104. 